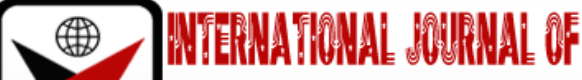

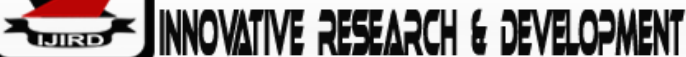

ISSN 2278-0211 (Online)

\section{Assessing the Builders' Role towards Sustainable Construction Industry Development in Nigeria}

\author{
Dr. Nwabueze Michael Anosike \\ Senior Lecturer, Federal University of Technology Owerri, Nigeria
}

\begin{abstract}
:
Statutorily, Professional Bodies such as the Nigerian Institute of Building (NIOB) and its Council of Registered Builders of Nigeria (CORBON) remains significant construction industry (CI) stakeholder in the development of sustainable construction industry in Nigeria going by the Government mandate backing its operation. This paper aims to examine the contribution of the professional builders in the development of sustainable construction industry in Nigeria. List of Registered Professional Builders (RPBs) and Registered Consultancy Firms (RCFs) as well as the list of Nigerian States, LGAs and their population distributions were obtained and adopted for the study to examine the level of spread of these professionals and their services across Nigeria using her six Geo-Political Zones (GPZ). Data was elicited from the professional body's periodic publications of qualified licensed practitioners and their location within a given period. Data analyzed revealed that Lagos State hosts the highest number of RPBs and RCFs with (553) and (12) respectively, followed by FCT with (359) RPB and (8) RCFs respectively. South-West Zone which has six States and accounts for (19.65\%) of the Nation's population produced the highest number of RPBs (809) and (13) RCFs respectively. North-East with six States and (112) LGAs accounted for $13.55 \%$ of the Nation's population, produced the least number of RPB of (84) and (1) RCF respectively. The results obtained may imply that the level of construction activities is highest in Lagos State. Also, twenty states out of the total (37) states did not produce any RCF and only Jigawa State produced the least number of RPB with (01) value. These appalling results obtained pose challenges to CI stakeholders including CORBON, NIOB, NUC, Tertiary institutions and Government at all levels in the quest to develop a sustainable CI in Nigeria.
\end{abstract}

Keywords: Construction industry, registered professional builder, sustainable development

\section{Introduction}

The significance of the construction industry (CI) to any Nation's development aspirations cannot be overemphasized. For instance, NBS (2012) indicates that within the years 2010, 2011 and 2012 the CI contributed 2.67\%, $2.84 \%$ and $3.01 \%$ respectively to Nigeria's Gross Domestic Product (GDP), with growth rate of $11.97 \%$, $11.85 \%$ and $12.26 \%$ in the years 2009, 2010 and 2011 respectively. However, Onashile (2012) posits that a vibrant CI signifies an industry working at about full capacity and therefore with minimum unemployment rate along with a desirable low risk of social problems and by extension assures stability of the sector and nation's economy. This paper aims to examine the contributory efforts of the RPBs towards meeting the development needs of the CI sector and the economy in general over the years in line with its statutory mandate in Nigeria.

\section{Literature Review}

According to Sharma (2008) the CI covers various forms of activities ranging from small mud house and village road construction to the construction of high-rise buildings, industrial structures, expressways, bridges, major dams, barrages, power houses, and other building and civil infrastructures. It further notes that the CI sector is basic to the development of any National activity like agriculture, industry, economic infrastructures, water, power, transportations and communication. He argues that the $\mathrm{CI}$ also acts as a stepping stone in all industrial activities, and also offers an environment to raise the standard of living of the people of a country. Sharma (2008) further states that the construction industry belongs to the capital goods of the economy and produces assets in the form of buildings, airports, etc. which add to the Gross National Product (GNP) as capital assets and at same time increases the productivity of other sectors of the economy. That, it is well known fact that all sectors of the economy, whether infrastructural, industrial, financial, mining or even irrigation and agricultural have certain components of construction work associated with them, though in varying proportions.

Sharma (2008) concludes that the implementation of a project is an investment decision for the development of the country from social and economic considerations, and the national development policy would aim at a rapid increase 
in national income or its distribution or both. The GDP in itself is used as a barometer to measure economic development of a Nation within a given period. Ajanlekoko (1990) affirms that the CI is a prime motivator of any economy; and in Nigeria, the CI represents about $60 \%$ of the capital investment.

The World Bank attributes the CI to account for between 3\%-8\% of the GDP in developing countries. Hillebrandt (2000) opines that the sector forms a crucial focus of any nation's economy. Plessis (2007) views the CI as a large sector of the economy responsible for millions of jobs and a significant proportion of GDP in most countries. Thus, \{Eteama, 2011; Ibrahim, 2011; NBS, (ND)\} posits that there is a correlation between GDP growth rate and unemployment. In the same light, Ogwumike (2012) submits that, when CI is properly connected to other sectors of the economy the sector's impacts on economy are tremendous.

The concept of sustainable development was defined by the UN Common Future (Brundtland World Commission on the Environment \& Development) Report of 1987 as "development that meets the present without compromising the ability of future generations to meet their needs". According to Energie (2000) sustainable development is that development that ensures minimal impact to the environment and also involves such a development that does not affect the sustenance of the future generation. Development on the other hand is defined by OGSG (2005) as "the carrying out of any building, engineering or mining or other operation in, on, over or under any land, and the making of any environmentally significant change in the use of land, building or structure or the conversion of any land, building or structure from its established or approved use including the placing or display of advertisement on the land, building or structure"

Whereas, Sandy (2008) referred to sustainable construction to include the choice of materials that are renewable over the non-renewable ones and also that the materials chosen should be used as efficiently as possible to allow for their eventual future reuse. In a related development, Section 1(1.1) of the National Building Code (NBC) asserts that it was in the bid to enhance the development of sustainable CI that it was evolved with the objectives to eradicate the ugly circumstances prevailing in Nigeria at the time, such as, incessant collapse of buildings; fire infernos; built environment abuses and other disasters; use of non-professionals and quacks and lack of maintenance culture (FRN, 2006).

According to Anosike, (2011) all the key professions recognized by the NBC (FRN 2006) are major stakeholders to the development of the CI in Nigeria. As a matter of fact, the contributions of these professions vary in accordance with their operating mandate. The Nigerian Institute of Building (NIOB 2011) asserts that a profession is a type of job that needs special training or skill, especially one that needs a high level of education and orientation. In this light FRN, (2006) defined a registered construction professional as one who shall be a technically and legally qualified person who has a valid registration/license to practice the profession issued by a relevant statutory regulatory body established for the control of that profession in Nigeria. To key into these definitions NIOB, (2011) defined a registered professional builder as a specialist who has received an approved standard of professional training and practice in construction technology, building production management, building surveying, maintenance management, cost estimation and tendering, building services, construction management, project management, etc. as well as sufficient experience, and statutorily registered by the Council of Registered Builders of Nigeria (CORBON) to practice the profession. And that the licensed professional builder may also be involved in building education, research and development. OGSG (2005) identifies a person registered and recognized to practice a profession in Nigeria must be, for example, "a Builder registered as a member of the CORBON.

Further, seven professions in the CI such as - building, architecture, among others and their respective Regulatory Bodies are recognized in Nigeria as major CI stakeholders (FRN, 2006; OGSG, 2005). As a result, certain Sections of the NBC recognized the job roles of each of the professions, for example, Section 2.21, 2.24 and 2.32(c) specified that a registered builder is that professional empowered to prepare a building condition survey report, building maintenance manual, construction works programme, project quality management plan and project health \& safety plan.

Other duties of the registered builder are found in the NBC, Section 13.12.4 which states that he shall be responsible for the daily "management of the execution of the building works including the supervision of artisans and tradesmen" and Section 15 (compliance form) of the same code empowers the professional builder to attest to the proper carrying out of works at different stages such as - setting out, foundation/basement works, roofing and closing-up works, superstructure works, mechanical installation, electrical services installations and finishes works along with other concerned professionals before the works could be accepted to have been executed in accordance with the set quality and standards. In the same light, with reference to the OGSG (2005), Section 291.5(1) (b). (vii) and Section 438.11(1). (c).9vi) recognizes the builder as a member of the Ogun State Urban \& Regional Planning Board and Local Planning Authority respectively.

The regulated and other professions (Miscellaneous Provisions) Act 1978 recognized the building profession as one of the scheduled professions in Nigeria and Decree No.45 of 1989 (now ACT CAP 40 of 1990) gave legal backing and recognition to the Building profession and also established the Council of Registered Builders of Nigeria (CORBON) by ACT CAP B.13 LFN, (2004) to regulate the profession in all its ramifications (CORBON, 2012). In a nutshell, the building profession is therefore one of the statutorily recognized professions in Nigeria's CI which main role in the CI sector is to collaborate with other allied professions in the realization of the dreams of the client and designers of construction structures with physical products that satisfies specifications and standards. Thus, the main thrust of this study being to evaluate the level of contribution of the professional builder in the development of a sustainable construction practice in Nigeria.

\subsection{The Vision and Mission Statement of the NIOB}

The vision of the Building program is to provide professional excellence and leadership for sustainable shelter. Whereas the mission is to enable members deliver with relevant stakeholders, sustainable shelter that addresses the housing needs of the Nation through research and development while complying with global best practices (NIOB 2011). 


\subsection{Objectives of the $N I O B$}

The objectives as set out in the NIOB constitution are to;

- Promote science and practice of building technology, building maintenance, building surveying, building production/construction management and project management including all research and publications of the results for public benefit.

- Establish and maintain a high standard of competence and conduct of those engaged or about to be engaged in the said science and practice of building and the education and research connected therewith.

- Promote and stimulate the improvement of the technical and general knowledge of persons engaged or training to be engaged in the building profession.

- Promote an understanding of the building profession among members of the public and to confer with all professionals and other bodies within the construction industry and to act as the sole authority in the federation of nigeria with regards to all matters affecting the profession.

- Act as the body which the government or other official or unofficial authorities or organization(s) in nigeria can seek advice, assistance or the expression of views on any subject of concern or interest to the building profession in nigeria.

\subsection{Background of the Building Profession}

The NIOB is the statutory professional training institute for building graduates and those who are about to be engaged in the Building Profession. According to NIOB, (2012) the professionalization of building materialized when the Chartered Institute of Building (CIOB) was established in the United Kingdom (UK) in 1834. Over a century later, specifically in 1967 the building profession was inaugurated in Nigeria by the NIOB as the first ever overseas centre of the U.K. CIOB. The NIOB gained its autonomy from the CIOB in May, 1970. After many years of successful and recognized activities, the institute gained its statutory backing through the Builders' (Registration, etc.) Decree NO. 45 of 1989 (now B.13 LFN, 2004) from the Federal Government of Nigeria. Consequently, the Council of Registered Builders of Nigeria (CORBON) was officially inaugurated on 24th April, 1990.

Presently, the membership strength of the institute is estimated at over five thousand across grades of fellows, corporates, graduates, associates, licentiates and technicians with chapters of NIOB existing across the thirty-six (36) States of the Federation in addition to Abuja the Federal Capital Territory (FCT) (NIOB, 2012).

The Building profession is no doubt global and thus a noble one, as it is recognized and practiced in different parts of the world namely, the U.K., Australia, the United States of America (USA), Malaysia, Singapore, Hong Kong, South Africa, Ghana, Canada, Kenya, among others.

\subsection{Services Rendered by the Professional Builder}

The Federal Government has an approved standard professional scale of fees for the consultancy services being rendered by the different professionals in the CI which includes that of the Registered Professional Builder. For the PB his services include, management of building construction process, project management, building maintenance, building surveying, facility management, feasibility and viability studies, feasibility studies of abandoned projects, litigation and arbitration, variation and fluctuation, resident supervision, prime consultancy, among others (NIOB, 2012).

\subsection{Opportunities}

The services of a registered Builder could be engaged in the following institutions and organizations; construction industry firms, educational institutions, banks, finance, insurance, housing corporations, military establishments, oil industry, the three tiers of Government and their agencies.

Other employers are multinational institutions, real estate development firms and teaching in in secondary and tertiary institutions and research institutes. The builder could also practice as a registered consultant, contractor, manufacturer of construction materials, or as an entrepreneur.

\subsection{Capacity Building}

It is believed that shelter is critical to human existence and the need to master and overcome its complexity and complications demands that its production and maintenance requires the involvement of a particular discipline or group, not only to continue to develop but to be dynamic in its technology and management. The building profession is seen to fit this description (NIOB, 2012). According to the (CORBON, 2014) there are about twenty-five (25) Federal, State and Private Universities offering degree (B.Sc. (Honors) Building or Building Technology (B.Tech.)) programs and about forty (40) Polytechnics, Colleges of Technology and Education running Ordinary National Diploma (OND) and Higher National Diploma (HND) respectively as well as others undertaking National Certificate of Education (NCE Technical) programs in Building Technology respectively. Notable among these tertiary institutions are ABU, Zaria, University of Ife, Lagos and Jos, respectively; Yaba College of Technology, Lagos, Auchi Polytechnics, Edo State and Federal Polytechnics, Imo State respectively.

Some of the core courses that prepares the professional builder at school to play the role assigned to them are Building construction and construction materials, construction technology, building structures and thermodynamics, strength of materials, measurement of building works and services, building drawing, building production management, tendering, estimating and price analysis of building works, project management and information technology, professional practice, ethics and procedures and contract law and arbitration, application of ICT as well as the use of other software applications such as computer aided designs (CAD), AUTODESK, REVIT, PRIMAVERA, ORION, Project Management, 


\subsubsection{Auto CAD}

The minimum duration of the building program at both University and Polytechnics remains five (5) years and the admission requirement is the possession of at least five (5) ordinary level school certificate result at Credit pass levels obtainable at not more than two sittings from either National examination council (NECO), West African school certificate examination (WASCE), General certificate of education (GCE), National board for technical education bureau (NABTEB) or its approved equivalent. Three of the five subjects must include English language, Mathematics, Chemistry and Physics and any other one science subject. The requirements for admission into 2-year Ordinary National Diploma (OND) is at least four (4) ordinary level subjects obtained at credit level pass at not more than two sittings, three of which must be in English language, Mathematics and Physics. There is an abridged 1-year Industrial Training after OND before the prospective candidate is qualified to proceed for the final 2-year HND program.

At the professional level, the graduate builder is placed in his category by the professional institute (NIOB) upon registration and is required to fulfill a number of professional tutoring requirements before qualifying for corporate membership (MNIOB) and thereafter having further satisfied the regulatory body's stated requirements and passed relevant examinations, the applicant will now considered to be met all the requirements and therefore issued certificate and license to practice as a fully registered builder (R.Bldr) with the CORBON.

The mandatory continuous lifelong professional development (MCPD) platform is used to continually train and update the knowledge of members through organized conferences, seminars and workshops in order to be in tune with latest local and international technological developments in the CI across the globe (NIOB,2012). Postgraduate studies leading to the award of Master of Science and Doctor of Philosophy (M.Sc./PhD) degrees respectively in construction management, building services, project management, construction technology, facilities management are also run in the Department of Building of many Nigerian Universities such as Ahmadu Bello University (ABU), Zaria, University of Lagos, and University of Jos including other Universities abroad. The degree qualification in building is also a requirement for registration with the famed Chartered Institute of Building (CIOB) UK.

\subsection{Geo-Political Economy of Nigeria}

Nigeria is a federation composed of thirty-six (36) States in addition to the federal capital territory (FCT), the administrative territory located in Abuja and with a population of about 141million (NPC, 2006). However, it is widely believed that the population is growing very rapidly estimated to be about two hundred (200) million as at 2020. It is also a known fact that for reasons of politics, Nigeria was divided into six (6) Geo-political zones (GPZ) comprising of NorthEast, North-West, North-central, South-East, South-West and South-South, which are believed to have closer relationships in terms of climate, language, culture and tradition. There is a federal character commission (FCC) which determines how the country's resources are shared at any given point in time in order to ensure equitable distribution of the Nation's common wealth. The FCC in line with the constitutional provisions ensures mobility of labor and non-discrimination against any Nigerian by reason of state of origin, gender, disability, language and religion in terms of employment and job opportunities.

\section{Research Methodology}

Primary and secondary sources were utilized to gather data and information which were deployed in this study. The primary data were obtained from the publications of the NIOB and CORBON and the secondary data from reviewed literatures on related subject matter. The primary source of information is believed to be reliable because they form the core publications of the institutions which are statutory institutions in Nigeria. The primary data sort and collected are the list of qualified registered Builders usually updated and published from time to time by NIOB and CORBON respectively. Others are publications from the National population commission and National Bureau of statistics which also publish demographic data and economic development status of the country. It is these data that were analyzed and presented in the form of tables, frequencies, and percentages, among others in this study in a bid to evaluate the contributions of the professional builders' services towards the development of sustainable CI in Nigeria in line with its statutory mandate since inception. 


\section{Presentation of Results}

\begin{tabular}{|c|c|c|c|c|c|c|c|c|}
\hline$\frac{z}{n}$ & 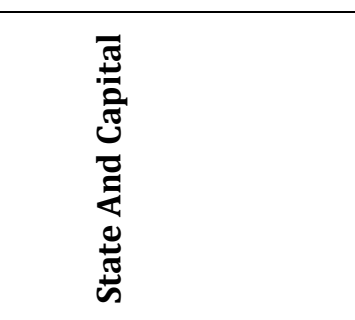 & $\begin{array}{l}0 \\
0 \\
0 \\
0 \\
0 \\
0 \\
0 \\
0 \\
0 \\
0\end{array}$ & 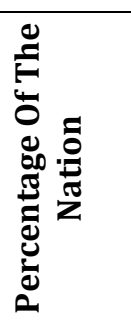 & 电 & 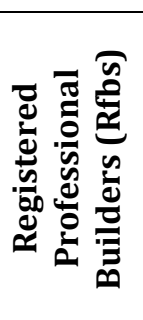 & 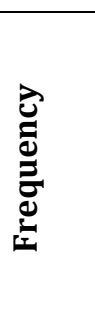 & 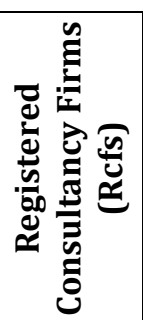 & 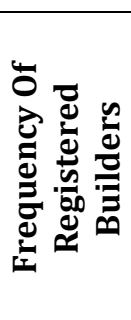 \\
\hline 1. & ABIA - Umuahia & $2,833,999$ & 2.02 & 17 & 24 & 24 & 1 & 1 \\
\hline 2. & ADAMAWA - Yola & $3,168,101$ & 2.26 & 21 & 8 & 32 & - & 1 \\
\hline 3. & AKWA IBOM - Uyo & $3,920,208$ & 2.80 & 31 & 12 & 44 & 2 & 3 \\
\hline 4. & ANAMBRA - Awka & $4,182,032$ & 2.99 & 21 & 36 & 80 & 1 & 4 \\
\hline 5. & BAUCHI- Bauchi & $4,676,465$ & 3.34 & 20 & 24 & 104 & - & 4 \\
\hline 6. & BAYELSA - Yenogoa & $1,703,358$ & 1.22 & 08 & 13 & 117 & - & 4 \\
\hline 7. & BENUE - Makurdi & $4,219,244$ & 3.01 & 23 & 23 & 140 & - & 4 \\
\hline 8. & BORNO - Maiduguri & $4,151,193$ & 2.97 & 27 & 21 & 161 & - & 4 \\
\hline 9. & $\begin{array}{l}\text { CROSS RIVER - } \\
\text { Calabar }\end{array}$ & $2,888,966$ & 2.06 & 18 & 9 & 170 & 1 & 5 \\
\hline 10. & DELTA - Asaba & $4,098,391$ & 2.93 & 25 & 14 & 184 & 1 & 6 \\
\hline 11. & EBONYI - Abakaliki & $2,173,501$ & 1.55 & 13 & 6 & 190 & - & 6 \\
\hline 12. & EDO - Benin City & $3,218,332$ & 2.30 & 18 & 26 & 216 & 1 & 7 \\
\hline 13. & EKITI - Ado Ekiti & $2,384,212$ & 1.70 & 16 & 54 & 270 & - & 7 \\
\hline 14. & ENUGU - Enugu & $3,257,298$ & 2.33 & 17 & 13 & 283 & - & 7 \\
\hline 15. & FCT - Abuja & $1,405,201$ & 1.00 & 06 & 359 & 642 & 9 & 16 \\
\hline 16. & GOMBE - Gombe & $2,353,879$ & 1.68 & 11 & 18 & 660 & 1 & 17 \\
\hline 17. & IMO - Owerri & $3,934,899$ & 2.81 & 27 & 21 & 681 & 2 & 19 \\
\hline 18. & JIGAWA - Dutse & $4,348,649$ & 3.11 & 27 & 1 & 682 & - & 19 \\
\hline 19. & KADUNA - Kaduna & $6,066,562$ & 4.33 & 23 & 53 & 735 & 1 & 20 \\
\hline 20. & KANO - Kano & $9,383,682$ & 6.70 & 44 & 24 & 759 & - & 20 \\
\hline 21. & KATSINA - Katsina & $5,792,578$ & 4.14 & 34 & 6 & 765 & 1 & 21 \\
\hline 22. & KEBBI - Birnin Kebbi & $3,238,628$ & 2.31 & 21 & 25 & 790 & - & 21 \\
\hline 23. & KOGI - Lokoja & $3,258,487$ & 2.33 & 21 & 12 & 802 & - & 21 \\
\hline 24. & KWARA - Ilorin & $2,371,089$ & 1.69 & 16 & 20 & 822 & - & 21 \\
\hline 25. & LAGOS - Ikeja & $9,013,534$ & 6.44 & 20 & 553 & 1375 & 12 & 33 \\
\hline 26. & NASARAWA- Lafia & $1,863,275$ & 1.33 & 13 & 14 & 1389 & - & 33 \\
\hline 27. & NIGER - Minna & $3,950,249$ & 2.82 & 25 & 32 & 1421 & - & 33 \\
\hline 28. & OGUN - Abeokuta & $3,658,098$ & 2.61 & 20 & 69 & 1490 & - & 33 \\
\hline 29. & ONDO - Akure & $3,441,024$ & 2.46 & 18 & 25 & 1515 & - & 33 \\
\hline 30. & OSUN - Osogbo & $3,423,535$ & 2.45 & 30 & 48 & 1563 & 1 & 34 \\
\hline 31. & OYO - Ibadan & $5,591,589$ & 3.99 & 33 & 60 & 1623 & - & 34 \\
\hline 32. & PLATEAU - Jos & $3,178,712$ & 2.27 & 17 & 40 & 1663 & 1 & 35 \\
\hline 33. & RIVERS - PortHarcourt & $5,185,400$ & 3.70 & 23 & 23 & 1685 & 2 & 37 \\
\hline 34. & SOKOTO - Sokoto & $3,696,999$ & 2.64 & 23 & 5 & 1690 & 1 & 38 \\
\hline 35. & TARABA - Jalingo & $2,300,736$ & 1.64 & 16 & 4 & 1694 & - & 38 \\
\hline 36. & YOBE - Damaturu & $2,321,591$ & 1.66 & 17 & 9 & 1703 & - & 38 \\
\hline 37. & ZAMFARA - Gusua & $3,259,846$ & 2.33 & 14 & 1 & 1704 & - & 38 \\
\hline 39. & NOT PLACED & - & - & - & 1 & 1705 & 1 & 39 \\
\hline & Total & $140,003,542$ & $100 \%$ & 774 & 1705 & 1705 & 39 & 39 \\
\hline
\end{tabular}

Table 1: Distribution of Builders in Nigeria According to State, Population and Lgas Source: NPC, 2006; NIOB, 2013 and Author's Field Study, 2020 


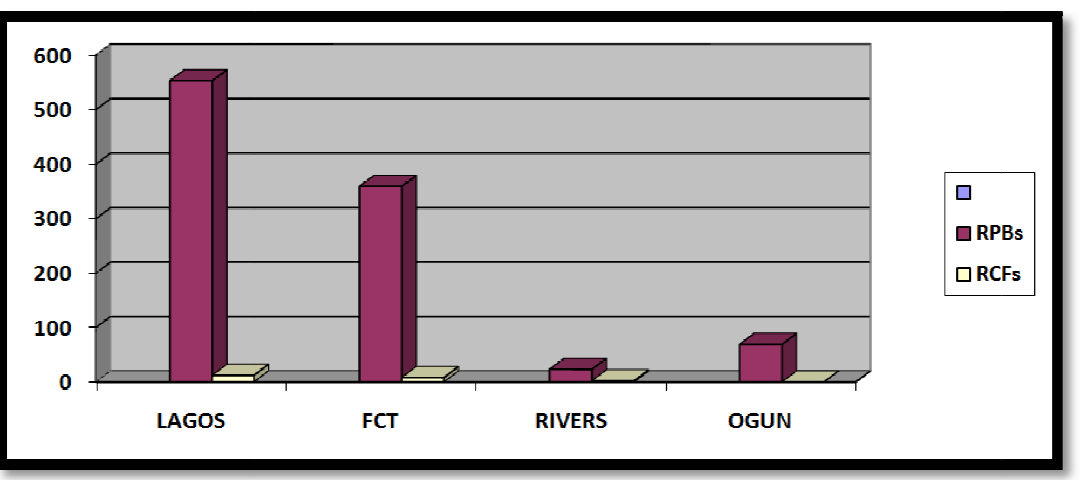

Figure 1: Comparing States with the Highest Number of Qualified Builders and Their Consultancy Firms

Source: Author, 2020

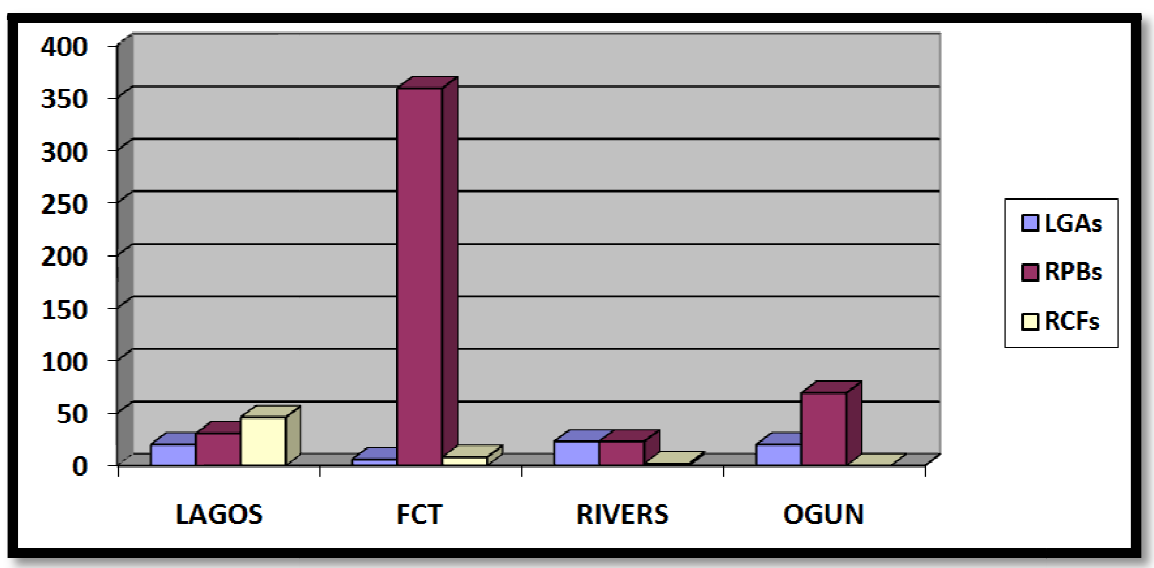

Figure 2: Comparing Number of Lgas and RPB Firms amongst States Source: Author, 2020

\begin{tabular}{|c|c|c|c|c|c|c|c|c|}
\hline$\frac{z}{n}$ & 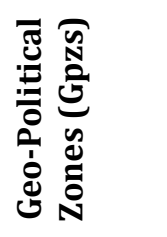 & 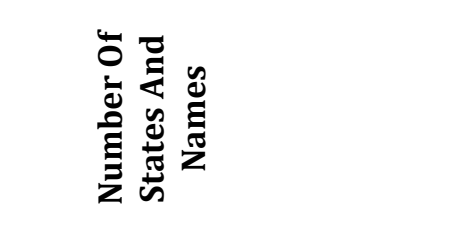 & 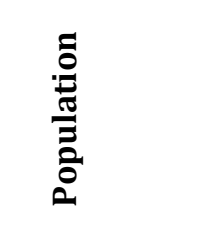 & 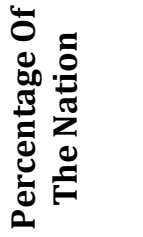 & జ్ర & 莺 & $\frac{n}{2}$ & $\underset{\check{U}}{\mathscr{y}}$ \\
\hline 1. & $\begin{array}{c}\text { NORTH- } \\
\text { EAST }\end{array}$ & $\begin{array}{c}\text { SIX STATES:- Adamawa, Yobe, } \\
\text { Bauchi, Borno, Gombe \& } \\
\text { Taraba }\end{array}$ & $18,971,965$ & $13.55 \%$ & 112 & 112 & 84 & 01 \\
\hline 2. & $\begin{array}{l}\text { NORTH- } \\
\text { WEST }\end{array}$ & $\begin{array}{c}\text { SEVEN STATES: - Jigawa, } \\
\text { Kaduna, Kano, katsina, Kebbi, } \\
\text { Sokoto \& Zamfara }\end{array}$ & $35,786,944$ & $25.56 \%$ & 186 & 298 & 117 & 03 \\
\hline 3. & $\begin{array}{l}\text { NORTH- } \\
\text { CENTRAL } \\
\text { \& FCT } \\
\end{array}$ & $\begin{array}{c}\text { SIX \& FCT: - Benue, FCT, } \\
\text { Plateau, Kogi, Kwara, } \\
\text { Nasarawa \& Niger }\end{array}$ & $18,841,056$ & $13.46 \%$ & 121 & 419 & 500 & 09 \\
\hline 4. & $\begin{array}{l}\text { SOUTH- } \\
\text { EAST }\end{array}$ & $\begin{array}{l}\text { FIVE STATES: - Abia, Imo } \\
\text { Anambra, Ebonyi \& Enugu }\end{array}$ & $16,381,729$ & $11.70 \%$ & 95 & 514 & 100 & 4 \\
\hline 5 & $\begin{array}{l}\text { SOUTH- } \\
\text { WEST }\end{array}$ & $\begin{array}{l}\text { SIX STATES: - Ekiti, Lagos, } \\
\text { Ogun, Ondo, Osun \& Oyo }\end{array}$ & $27,511,992$ & $19.65 \%$ & 137 & 651 & 809 & 13 \\
\hline 6. & $\begin{array}{c}\text { SOUTH- } \\
\text { SOUTH }\end{array}$ & $\begin{array}{l}\text { SIX STATES: - Akwa Ibom, } \\
\text { Bayelsa, Cross River, Delta, } \\
\text { Edo \& Rivers }\end{array}$ & $21,014,655$ & $15.01 \%$ & 123 & 774 & 97 & 7 \\
\hline & TOTAL & 37 STATES \& FCT & $140,003,542$ & $100 \%$ & 774 & 774 & 1705 & 39 \\
\hline
\end{tabular}

Table 2: Distribution of Builders in The Six Geo-Political Zones (GPZs) According to The Number of States, Population and Local Government Areas (LGAs) In Nigeria Sources: NPC, 2015; NIOB, 2013 and Author's field study, 2020

\section{Results and Discussions}

Result obtained in Table 1 indicates the 37 States of the Federation including Abuja, the FCT. A row was created in Table 1 to identify qualified builders (1) whose address and location could not be identified at the time the document was published. Further, the result in Table 1 shows that the highest number of RPBs obtained was (553) representing those 
practitioners located in Lagos State, followed by FCT, Abuja as the second highest with (359) RPBs. The third highest number of RPB with nine (9) building practitioners is Rivers State, indicating a very sharp gap between the second and third highest values.

Similarly, out of a total of (37) RCFs recorded in Table 1, Lagos State produced the highest number of RCFs with (12) practitioners and FCT the second highest with (8) RCF. It is further observed from Table 1 that (20) out of the total (37) States did not produce any RCF whereas, three of the States produced (2) each of RCF and nine States produced (1) each of RCF, respectively.

The result obtained for the first and second highest positions respectively may not be unexpected as it may be an indication that these States engage in high level of capital projects provisioning in Nigeria. The third highest which is Ogun State is believed to host the highest number of tertiary institutions in Nigeria. This may indicate that a lot of construction activities also thrive in Ogun State and the fact that a number of the various tertiary institutions in Ogun State must have engaged the services of the RPB in their physical planning and works departments as well as employed them for teaching/lecturing services at the existing secondary and tertiary institutions. The first and second lowest number of RPB with (01) values respectively are Jigawa and Zamfara States. This result may indicate that there is paucity of construction activities and infrastructural provisioning in these two States.

This line of thought may equally be used to imply that there is lack of or poor building and civil engineering maintenance activities in these states. In order words, the construction activities may be said to have been compromised with quacks in these two States. However, noteworthy from the result in Table 1 is the fact that in all the thirty-seven States of the Federation there is at least an RPB. Notable, though sadly also is the fact that a high number of States (20) representing $54 \%$ of the (37) States of the Federation does not engage the services of any RCF. Paradoxically, even Kano State which results obtained indicates as the most populated State with over 9 million people does not have a single RCF to meet the State's capital project investment needs. In sum, the number of RCF (38) recorded across Nigeria with an estimated over 141 million people is a big challenge to CORBON, CI and Nigeria in general.

In a related development, it is notable in Table 2 that Nigeria is divided into six Geo-Political Zones (GPZ) comprising of South-West which has six States and accounts for (19.65\%) of the Nation's population produced the highest number of RPBs (809) and (13) RCFs; North-Central accounting for $13.46 \%$ of the total population produced the second highest number of RPBs of (500) and (9) RCFs respectively; North-East with six States and (112) LGAs accounting for $13.55 \%$ of the Nation's population produced the least number of RPBs of (84) and (1) RCF; North-West with seven States and (186) LGAs with total population of (25.56\%) can only boost of (117) RPBs and (03) RCFs; South-East with five states and a population of (11.70\%) has (00) RPBs and (04) RCFs; and last but not the least, south-south Zone which has six states with total population of (15.01\%) of the Nation's total population engaged the services of (97) RPBs and (7) RCFs. Similarly, Figure 1 which was used to compare the first four States with the highest number of RPBs and their firms indicated that Lagos State was ranked $1^{\text {st }}$ and Rivers State the least number of RPBs. Results shown in Figure 2 indicates that FCT with (6) LGAs produced the highest number of RPBs as compared to Rivers with (23) LGAs producing the least number.

\section{Conclusions}

The role of the professional builder in the development of a sustainable CI is significant and the profession of Building is noble, global, well thought out, and backed by enabling statutes and assigned specific job roles \{FRN, 2006; CORBON, 2012; NIOB, 2012; OGSG, 2005; CIOB\}. The academic and professional training the builder undergoes as well as the duration of these trainings before being licensed to practice is perceived in this study to be adequate to equip him for the technical and professional services being rendered. Notable amongst her roles is an extract from the NBC Section 13.12.4 which states that the professional builder "shall be responsible for the daily management of the execution of the building works including the supervision of artisans and tradesmen" (FRN, 2006). The implication of this role is that a good number of builders would be required to carry out this duty on a medium or large-scale construction project such as a shopping mall of Shoprite magnitude, institutional projects, housing estates development projects, amongst others.

The earlier referenced section of the NBC requires that the services of licensed builders should be maximized on any project by assigning them to different trades on the same project such as, a builder to manage the block work only aspect of the works; so also, a builder to handle only the concrete work aspect; a builder for structural steel works; a builder for electrical and mechanical services works, a builder for finishes aspects respectively. This implies that such a project may require the services of many professionally qualified builders for optimum service delivery in order that the client will receive value for money deployed.

Apparently, the number of registered PBs (1708) in Nigeria with over 141million population is a far cry when compared to their role in the CI in Nigeria as being attested in this study. This is thus a colossal challenge to CI stakeholders including NIOB, CORBON, tertiary institutions, NUC and Government at all levels in the development of a sustainable CI construction policy and its implementation in Nigeria.

\section{References}

i. Anosike, M. N. (2011). Parameters for Good Site Concrete Production Management Practice in Nigeria, Unpublished PhD thesis, Covenant University, Ota, Nigeria

ii. Energie (2000). Sustainable Urban Design. A publication funded under the EU's 5th framework program for research, technological development \& demonstration, Energy research group, Dublin, Ireland

iii. Eteama, H. C. (2011. The Economics of Building and Construction in Nigeria's Development, Proceedings of the $1^{\text {st }}$ Annual building construction economic round-table conference by QSRBN, June 14 \& 15, 2011, Abuja. P.1-19. 
iv. Federal Republic of Nigeria (FRN, 2006). National Building Code. $1^{\text {st }}$ ed. LexisNexis, Butterworth's publishers.

v. Ibrahim, A. D. (2011). Developing a Vibrant Construction Sector in Nigeria: Issues, Strategies and Challenges, Proceedings of the $1^{\text {st }}$ Annual building construction economic round-table conference by QSRBN, June 14 \& 15 , 2011, Abuja. P.88-98.

vi. National Bureau of Statistics (NBS, 2011) Assessed via Google and retrieved on 20 ${ }^{\text {th }}$ Feb, 2015

vii. National Population Commission website, assessed via Google and retrieved on 20 ${ }^{\text {th }}$ Feb, 2015

viii. The Nigerian Institute of Building (NIOB, 2012). Ogun Chapter: Proceedings from the Annual Lecture "Nigerian Construction Industry Reform-A hope \& an imperative for adequate performance" 21 ${ }^{\text {st }}$ Sept, 2012.

ix. The Nigerian Institute of Building (NIOB, 2011). Oyo State Chapter: Building Profession, the core of the building industry.

x. Ogun State of Nigeria: Ogun State Urban and Regional Planning Law 2005

xi. Council of Registered Builders of Nigeria (CORBON, 2012). List of Registered Builders entitled to Practice in the Federal Republic of Nigeria, 2012 edition.

xii. Nigerian Institute of Quantity Surveyors (NIQS, 2013). The Report of the 2011-2013 National Executive Council.

xiii. Nigerian Institute of Quantity Surveyors (NIQS, 2015). Diary Publications.

xiv. Sharma, S. C. (2008). Construction Engineering \& Management, Khanna publishers, Delhi-India.

xv. Ogwumike, F. O. (2012). The Importance of Building and Construction Sector in Employment and Poverty Alleviation in Nigeria, Proceedings, $2^{\text {nd }}$ Annual Building \& Construction Economic Round-Table (BCERT 2), July 12 $\& 13,2012$, Abuja. 